\title{
"We're in This Together": Bridging and Bonding Social Capital in Elementary School PTOs
}

\author{
Brittany Murray iD \\ Thurston Domina \\ University of North Carolina at Chapel Hill \\ Amy Petts \\ Linda Renzulli \\ Rebecca Boylan \\ Purdue University
}

Scholarship on the links between families and schools encompasses contradictory notions about social capital and its relation to inequality. One view holds that schools can narrow inequality by generating dense relationships among families, while others suggest that advantaged parents can use these networks to hoard opportunities. This multiple case study analyzes qualitative data from diverse North Carolina elementary schools to learn how parents build and deploy social capital. We distinguish between bonding social capital, built in dense, homogeneous networks, and bridging social capital, gained through relationships across a social distance. Our analyses suggest that bonding alone is associated with opportunity hoarding; however, when schools are committed to building both bridging and bonding social capital, they can produce more equitable and inclusive schools.

KEYworDs: diverse schools, inequality, opportunity hoarding, parentteacher organizations, social capital

$\mathrm{R}^{\mathrm{s}}$ esearch on the links between schools and families reveals an ambiguous relationship between social capital and educational inequality. Many scholars argue that placing students at the center of dense and long-standing social networks helps mitigate socioeconomic inequality (Astone \& McLanahan, 1991; Carbonaro, 1998; Coleman, 1988; Teachman et al., 1997). The research on the Catholic school effect exemplifies this tradition, attributing excellent and equitable outcomes in these schools to the tightknit communities they foster. A more critical tradition, however, points to instances in which socially advantaged families use their networks to maintain or exacerbate inequality (Bourdieu, 1986; Calarco, 2018; Cucchiara \& 
Horvat, 2009; Lareau, 2000; Lareau \& Calarco, 2012; Lewis \& Diamond, 2015). This is evident when advantaged parents use information networks to navigate school choice policies (Ball \& Vincent, 1998; Fong \& Faude, 2018; Sattin-Bajaj et al., 2018) and work collectively to influence curriculum and course assignment practices (Lewis \& Diamond, 2015; Oakes, 2005) and the allocation of educational resources (Lewis-McCoy, 2014; Posey-Maddox, 2014).

In this article, we examine the different forms of social capital that parents generate and how these forms relate to educational equity using a multisite comparative case study in North Carolina public elementary schools. Our case studies, which are based on observational, interview, and textual data on parent-teacher organizations (PTOs) and other formal and informal parent interactions, describe the structure of social connections among actors in schools and the ways in which parents and educators use their relationships to create and allocate educational opportunities. We focus particular attention on school practices that shape the formation of social ties

Brittany Murray is a PhD candidate in the School of Education at the University of North Carolina at Chapel Hill, 122 Peabody Hall CB\# 3500, Chapel Hill, NC 27599, USA; e-mail: bcmurray@live.unc.edu. Her research examines the relationship between social and political processes in schools and educational inequality. She uses mixed-methods to investigate relationships between race, parents, the organization of schools, and the distribution of school resources and learning opportunities.

Thurston Domina is an associate professor of educational policy and sociology in the School of Education at the University of North Carolina at Chapel Hill. His work documents educational inequalities and looks for educational policies and strategies that help create a more just, equitable, and inclusive society. He uses a range of analytic tools to understand how families influence children's educational opportunities, the ways schools accommodate learners' diverse needs, and the consequences of educational experiences for child development and the transition to adulthood.

Amy PetTs is a PhD candidate in sociology at Purdue University, West Lafayette. Her research interests center around race and understanding patterns of racial inequality in the United States.

Linda Renzulli is a professor of sociology and Department Head in the College of Liberal Arts Department of Sociology at Purdue University, West Lafayette. Her scholarly interests include sociology of education, organizational change, and stratification. Her recent work concentrates on schools as organizations, examining the causes and consequences on student stratification that result from the development of charter schools.

ReBecca Boylan is a postdoctoral researcher in the College of Liberal Arts Department of Sociology at Purdue University, West Lafayette. Rebecca is particularly interested in the factors that shape students' movement through educational institutions over time. Utilizing large-scale data sets and quantitative methodologies, she explores how schools and individuals interact to shape mobility and has examined students' return to education after high school dropout and the causes and consequences of students' long-term postsecondary trajectories. 
Murray et al.

in schools and how parents leverage those relationships for educational gain.

Using recent theory and evidence on school-family links as well as social network theory, we build on Robert Putnam's distinction between bridging and bonding social capital. In Putnam's (2001) words, "bonding social capital creates a kind of sociological superglue, whereas bridging social capital provides a sociological WD-40" (p. 23). We use PTOs and other parent groups as a lens to view the construction of bonded and bridged relationships and their ensuing social capital, asking the following questions:

1. Is there variation in bridging and bonding parental social capital across schools?

2. How do parents and educators build bridging and bonding social capital in socially, economically, and/or racially diverse schools?

3. What is the relationship between the structure of parent social capital and the distribution of social and educational resources in the school?

Leaders in all the schools we study say that they are committed to building relationships with parents. However, our analyses suggest that the strategies educators use to engage families, the forms of social capital that parents and educators build, and the educational utility those networks generate vary substantially across the schools in our sample. In some schools, we find that decisions about the allocation of educational resources are inclusive and broadly distributed across diverse parent groups. In others, we find that advantaged parents use their networks to maintain exclusive access to or control over a renewable set of school resources to advantage their own children, a process we refer to as opportunity hoarding (Tilly, 1998). Our analyses suggest that the social structure of parent groups helps explain this variation. In the absence of bridging social capital (across diverse school actors), socially advantaged groups can use bonding social capital to hoard opportunities and reproduce inequality. Bridging social capital alone, however, is insufficient to establish the trust, reciprocity, and norms needed to sustain efforts at inclusion across diverse groups. In order to generate genuinely inclusive and equitable school communities, parents in traditionally marginalized social groups must forge strong within-group bonds in order to disseminate information, make sense of their children's experiences, and effectively advocate for organizational change.

Building on critical conceptualizations of social capital in diverse contexts (Lareau \& Horvat, 1999; Portes, 1998), this work highlights social processes that convert resources into educational advantages. We direct attention to school-level variation in parent organizing practices that create unequal control over resource allocation and decision-making processes. Our findings suggest that in the same way that schools can improve their educator effectiveness and satisfaction by attending to educator social 
networks (Daly, 2010), schools can facilitate the construction of parent networks that more equitably distribute information and educational resources. By illuminating the school practices that align with bridging and bonding social capital generation, we provide concrete strategies that school and parent leaders can use to build authentic school-parent partnerships that advance equity.

\section{Conceptualizing Social Capital}

As the concept of social capital has come into widespread use in educational scholarship, its meaning has become increasingly diffuse. We draw upon Lin's (1999) definition of social capital as a set of "resources embedded in a social structure which are accessed and/or mobilized in purposive actions" (p. 35). This definition directs attention to three key points. First, social capital exists in social relationships and is thus distinct from trust, culture, or other characteristics of the social structures in which it is embedded. Second, social capital created in relationships can be used collectively or to an individual's benefit. And finally, relationships are converted to social capital when they are used instrumentally. Thus, while friendly conversation may be a raw material from which social capital is built, it is not social capital until one or more conversationalist puts their relationship to use in pursuit of a goal.

Our analyses are concerned with parents' activation of social capital in the context of differential power dynamics, not just between schools and parents (Fine, 1993; Lareau \& Horvat, 1999; Lareau \& Muñoz, 2012; Noguera, 2001) but also among parents (Abrams \& Gibbs, 2002; PoseyMaddox, 2014). In doing so, we bring a critical lens to the literature on social capital in schools (Dika \& Singh 2002; Lareau \& Horvat 1999; Portes, 1998). Drawing upon the distinction between bonding and bridging social capital, we investigate when parent social networks are exclusive and facilitate opportunity hoarding and when they are more inclusive and facilitate more equitable educational experiences.

\section{Bridging and Bonding in Education Research}

Social capital can result from two types of network structures: bonding social capital characterized by strong, tight-knit relationships within peer networks and bridging social capital characterized by relationships between members of different social networks (Putnam, 2001). Bonding social capital is formed among individuals in close social proximity, such as in families, churches, or neighborhoods, and relies on solidarity, reciprocity, familiarity, and trust (Coleman, 1990b). Bridging social capital results when people connect across social distances to share resources, knowledge, and spaces. Bridging social capital facilitates innovation and the diffusion of ideas and 
Murray et al.

information across diverse stakeholders and groups (Burt, 2000; Frank et al., 2018; Granovetter, 1973; Putnam, 2001).

Existing research suggests that these two forms of social capital operate differently and have distinct implications for the distribution of opportunities. On one hand, social capital derived through bonds in heterogeneous communities may exclude people who are not members of highly bonded powerful groups (Bourdieu, 1986; Horvat et al., 2003; Lewis \& Diamond, 2015, Posey-Maddox, 2014). On the other hand, social capital derived through bridges alone may not build trust (Coleman, 1988). Research in other contexts demonstrates that a combination of weak and strong ties may be the most effective network structure to generate broad access and inclusion (Centola, 2011; Mutz, 2002). Similarly, schools may be able to best generate equitable outcomes when parents generate bonding and bridging social capital.

\section{Bonding Social Capital and the Reproduction of Educational Inequality}

Much of the existing research on school/family links emphasizes bonding social capital: the superglue that binds school actors within tight-knit groups characterized by similarities along dimensions of race, class, religion, or other social categories (Granovetter, 1973; Putnam, 2001). A rich sociological literature on Catholic schools, for example, describes how the dense, reciprocal, and intergenerational networks that exist among parents, educators, and students in these schools and their surrounding church communities benefit children (Coleman, 1988; Teachman et al., 1997). Catholic school parents and teachers often know one another before their children enroll, and this intergenerational closure facilitates the creation and enforcement of behavioral norms for children as well as the circulation of information about children's development (Dika \& Singh, 2002). Generalizing from the Catholic school literature, scholars hypothesize that dense reciprocal relations among parents, teachers, and students can mobilize school improvement efforts (Bryk et al., 2010; Coleman, 1988; Coleman, 1990a; Comer, 2015; Tedin \& Weiher, 2011). For example, Turley et al. (2017) find, through randomizing an after-school intervention, that providing conditions for parents to develop intergenerational closure, shared expectations, and reciprocity improves children's socioemotional behavior.

It is not clear, however, that bonding social capital is universally beneficial. Information exchanged through dense networks is often redundant and limited in scope (Borgatti \& Halgin, 2011; Granovetter, 1973; Uzzi, 1997). Actors in dense social networks often develop strong feelings of identity and use their social capital to exclude and stigmatize outsiders (Burt, 1999; Horvat et al., 2003; Posey-Maddox, 2014).

Social closure may be especially problematic in diverse and unequal settings. Actors with similar traits across demographic, behavioral, or status 
dimensions are most likely to form strong ties leading to the formation of bonded subgroups (Bridwell-Mitchell \& Cooc, 2016; McPherson et al., 2001). Information flows more readily within these groups or cliques, limiting the extent to which the diffusion of information and resources occur between groups (Burt, 2000). For example, expertise, support, and collaborative opportunities can be concentrated within cliques of high-skilled teachers (Coburn et al., 2013). Without intervention from school policy or leadership, these cliques reinforce inequality in teacher capacity by limiting the spread of information to newer, less skilled teachers (Frank et al., 2018).

Advantaged parents in racially and/or socioeconomically diverse schools may use bonding social capital to hoard educational opportunities for their own children (Bourdieu, 1986; Horvat et al., 2003; Lewis \& Diamond, 2015; Murray et al., 2019; Posey-Maddox, 2014). In the contemporary United States, affluent families dedicate a large and growing proportion of their wealth to the cultivation of norms, expectations, and habitus associated with educational success (Kalil et al., 2016; Reardon, 2011). These investments often lead the advantaged to accrue high levels of social capital, while high levels of stress, family and residential instability, and inconsistent work schedules contribute to isolation among poor and minority families (Crosnoe \& Cooper, 2010; Wilson, 1987). Bonding social capital helps facilitate opportunity hoarding by providing a conduit to socially valuable information for connected parents and their children. Parents use the information they glean via social bonds to identify desirable learning environments (Lareau \& Goyette, 2014; Useem, 1992), lobby for their children's inclusion in these environments (Domina et al., 2017; Lewis \& Diamond, 2015; Oakes, 2005), resist efforts to redistribute learning opportunities to less advantaged students (Lareau \& Muñoz, 2012; Lewis-McCoy, 2014), and socialize their children to effectively advocate for themselves in schools (Calarco, 2018).

\section{Bridging Social Capital and the Potential for More Inclusive School Communities}

In contrast, bridging social capital has the potential to create more equitable outcomes, particularly in socially heterogeneous communities. In these contexts, weak social ties between diverse constituencies can be essential for spreading information and building trust (Bryk \& Schneider, 2003). Bridging social capital is created when individuals build ties across social distance, making connections between individuals and communities that might otherwise be disconnected. This form of social capital creates mechanisms for groups within diverse communities to exchange knowledge and resources, making it easier for diverse groups to understand and account for one another's interests and needs (Larsen et al., 2004). Social capital thus facilitates coalition building in order to engage in civic action (Kim \& Schneider, 
Murray et al.

2005; Larsen et al., 2004). This exchange of information offsets opportunity hoarding (Burt, 2000; Minefee et al., 2018; Roscigno, 2007; TomaskovicDevey, 1993) and creates pluralistic communities in which diverse groups flourish (Portes, 1998; Small, 2009b).

Bridging social capital can link disadvantaged students to institutional actors who can provide social supports and help translate traditionally undervalued cultural and linguistic competencies into pathways for opportunity (Stanton-Salazar, 1997). Furthermore, intentional efforts to establish brokers can build bridging social capital between schools and underserved families by building trust and understanding, developing supportive networks between families, and building both educator and parent capacities to support children (Ishimaru et al., 2016). While bridging social capital cannot erase social distance and inequality-and indeed, in many cases, relatively advantaged groups have more access to bridges (Bridwell-Mitchell, 2017; Horvat et al., 2003; Lareau et al., 2018)—this form of social capital incorporates diverse constituencies into a common community and potentially creates opportunities for traditionally underserved groups to participate in educational processes (Shoji et al., 2014).

In this study, we examine the relationship between the forms of social capital operating among parents in schools and the extent to which parents from diverse racial/ethnic and socioeconomic backgrounds are able to fully participate in decision-making and resource-allocating processes. Rather than an intervention into the sociological literature on social capital or social network theory, we see our article as a contribution to scholarly and practitioner understanding of parental involvement in school. By applying the notions of bridging and bonding social capital to parents' activities in the school, we illustrate the relational foundations of effective parental school involvement. We use PTOs and other parent organizations to shed light on the ways in which parent relationships structure access to power and other valuable resources in the school. Our findings suggest that while advantaged parents can use bonding social capital as a tool to hoard power and resources, the construction of relational bridges across bonded parent groups can facilitate inclusive and broadly beneficial parental involvement in schools.

\section{Parent-Teacher Organizations as a Source of Social Capital}

Voluntary associations, such as PTOs, have long been a primary source in the study of social capital (e.g., Paxton, 1999; Putnam, 2001). Our own data, which provide the most comprehensive overview available of formal PTO activity in the contemporary United States, indicate that more than $60 \%$ of public elementary schools have a PTO or similar organization that files mandatory nonprofit tax records (Murray et al., 2019). These voluntary organizations are by no means the only source of social capital in schools. However, PTOs and other parent groups have historically been important 
nodes for collective action in schools (Putnam, 2001; Skocpol \& Fiorina, 2004; Woyshner, 2003). Paralleling tensions in the literature on social capital, existing research on PTOs is mixed. Putnam and others describe PTOs as a quintessential form of voluntary association and imply these organizations benefit the broader social good (Crawford \& Levitt, 1999). However, several studies document ways in which PTOs facilitate advantaged parents' opportunity hoarding (Murray et al., 2019; Posey-Maddox, 2014).

While most PTOs command modest financial or organizational resources, these voluntary organizations may structure parental interactions and create contexts for parents to meet and work with other parents (Small, 2009b). PTOs create channels for regular communication between parents, teachers, and school leaders, allowing parents to informally track their children's educational progress (Bryk et al., 2010; Comer, 1980; Lareau, 2000). As they attempt to represent "parents' interests" in the school and in policy matters that transcend the school, they likely help create a shared identity among parents and provide continuity in school communities even as some students leave and others enter (Polletta \& Jasper, 2001). Our analyses focus particular attention on PTOs and other formal and informal parent groups that facilitate the formation of social ties in schools.

\section{Data and Method}

We use a comparative case study design to investigate the processes by which parents and school staff build relationships. Our analyses draw on multiple data sources, including PTO revenue data from the Internal Revenue Service; school administrative data from the National Center for Educational Statistics (NCES); ethnographic observations; semistructured interviews; document review of budget, meeting minutes, and school communications; and social media analysis. We collected qualitative data during the 2016-2017 to 2017-2018 school years. PTOs served as a starting point for our qualitative work, and we also observed school-parent relationships forged in less formal settings, such as school-based volunteering and afterschool activities. Our study design allows us to examine school practices that facilitate the formation of bridged and bonded relationships among parents and how the organization of parent relationships influences the distribution of resources and opportunities among diverse school constituents.

\section{Case Selection}

We engaged in a multistep process to narrow the population of North Carolina elementary schools down to nine schools in which we collected qualitative data and four schools that we studied intensively. The goal in selecting cases for analysis was not to make broad generalizations about the characteristics of parent social capital across a representative set of schools but rather to deliberately select cases to compare and contrast using 
Murray et al.

a logical and theoretically informed set of criteria (Schensul et al., 1999). The replication of analyses in diverse school contexts improves our precision in documenting the underlying mechanisms involved in the relationship between parent networks and educational equity (Small, 2009a; Yin, 2014). This section describes the process we used to identify the range of possible schools and strategically select those that formed the focus of our analyses.

First, we focused our study on schools in North Carolina. North Carolina's public school population is diverse: $40 \%$ of the state's students are White, while 25\% are Black and 15\% are Latinx. A fifth of North Carolina public school children enroll in the federal free or reduced-price lunch program. Since most of the state's school districts are large countywide agencies that operate with a legacy of federal school desegregation enforcement, North Carolina public schools are less racially and economically segregated than elsewhere in the United States.

Second, we identified and gained permission to collect qualitative data in three districts-one urban, one suburban, and one rural. Each district enrolled a diverse group of students in relatively racially and socioeconomically diverse schools. Furthermore, based on our analysis of Internal Revenue Service data on PTOs described below, we could see that variation existed across the schools in each of these districts on the extent of formal parental organization. The leadership in each district was also eager to participate and facilitate introductions with school leaders. Finally, each of the three districts were located in relatively close proximity to one another, making it possible for the team to collect detailed data in all three districts at the same time.

Third, within each district we partnered with district administrators to select demographically diverse elementary schools, which varied in levels of parent organization. To identify schools, we drew on a panel of North Carolina elementary school demographic and enrollment data from NCES (Table 1) paired with annual PTO revenues obtained from nonprofit tax filings, which are mandatory for all nonprofits that generate more than $\$ 5,000$ in revenue annually. ${ }^{1}$ Within each district, we sampled at least one school with a high level of PTO activity, defined as a school whose PTO reports at least $\$ 25,000$ in annual revenue. In addition, within each district, we attempted to identify at least one school with a relatively inactive PTO, defined as a school in which the PTO reports revenue of less than $\$ 25,000$ annually. In the suburban district, in which there was no low-revenue PTO, we sampled the available school with the lowest revenue PTO as well as two very high-revenue schools.

Fourth, conducting key informant interviews and observing parent interactions in these schools, we observed a typology of bridging and bonding based on attributes of parent interactions. This distinction helped focus our selection strategy (Stake, 2006), leading us to intensify our data collection 


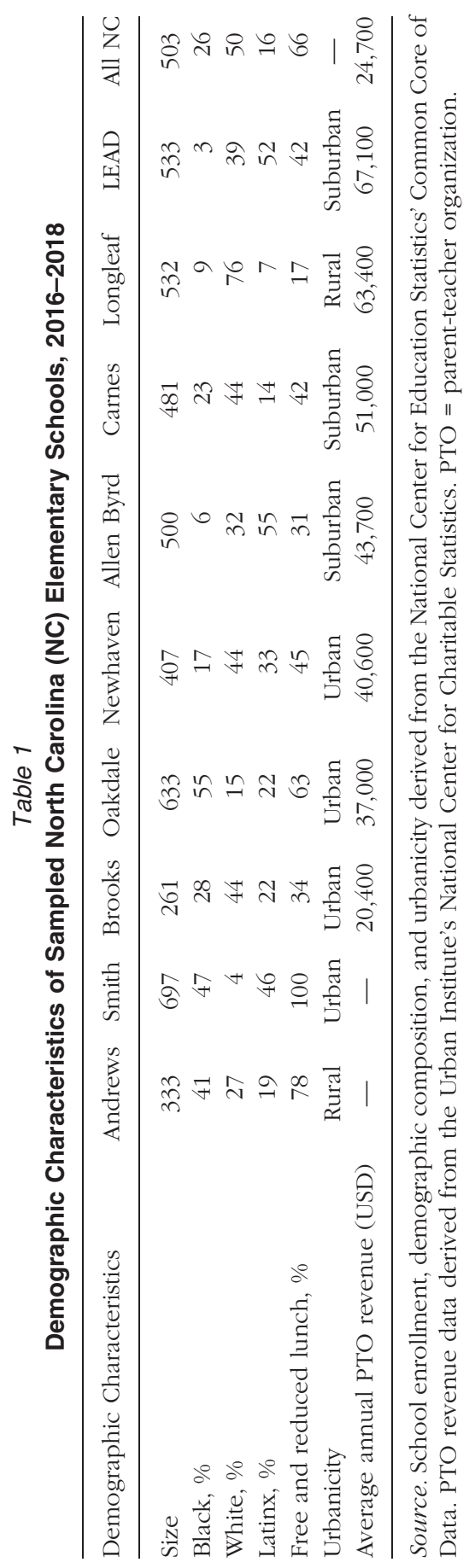


Murray et al.

efforts in the four schools that best exemplified this typology. These four schools, in which we collected multiple sources of data (described in the following section), are the centerpiece of our analyses. We use disparate sources of data to triangulate within-case and use data from the remaining five schools to triangulate across sites by cross-checking results and searching for disconfirming evidence (Greene et al., 1989; Stake, 2006).

\section{Data Sources}

Two research team members led fieldwork between the 2016 and 2018 school years collecting data on focal and nonfocal schools (see Table 2 for a comprehensive description of data collected). In all nine schools, we collected at least one semistructured interview from a key informant, such as an administrator, and observed at least one school event. In each of the four case study schools, we interviewed five to 10 parents, teachers, and administrators using a semistructured protocol; conducted ethnographic observations of PTO meetings and other informal parent gatherings; collected parent communications for review; and analyzed social media data.

\section{Semistructured Interviews}

We conducted semistructured interviews with 37 respondents: 18 parents, 11 teachers, and 8 administrators. Thirty of these interviews occurred in our four focal schools. Our primary goal in sampling respondents was to understand the mechanisms parents used in these schools to build and activate social capital. To that end, we used snowball sampling to learn the experiences of a racially and socioeconomically diverse set of parents from the following groups: (1) parents who were highly involved in formal organizations like PTOs, (2) parents who were involved in the school but not active in the PTO, and (3) parents whose involvement in the school was minimal. We identified respondents through recommendations from teachers and administrators and often relied on introductions from stakeholders to increase trust and willingness to participate (Biernacki \& Waldorf, 1981).

Interviews examined parents' expectations and communication with the school, relationships with other parents, and engagement with parent organizations. We probed for recurring school practices, both formal and informal, that facilitated opportunities for parents and educators to build relationships and deploy social capital. Additionally, we investigated power dynamics among parents, including which parents' were able to influence school organization, which parents' voices were marginalized, and who served as gatekeepers for resources, permissions, and so on. Each interview lasted approximately an hour, and each respondent received a $\$ 50$ gift card for their participation. All interviews were audio recorded and transcribed. 


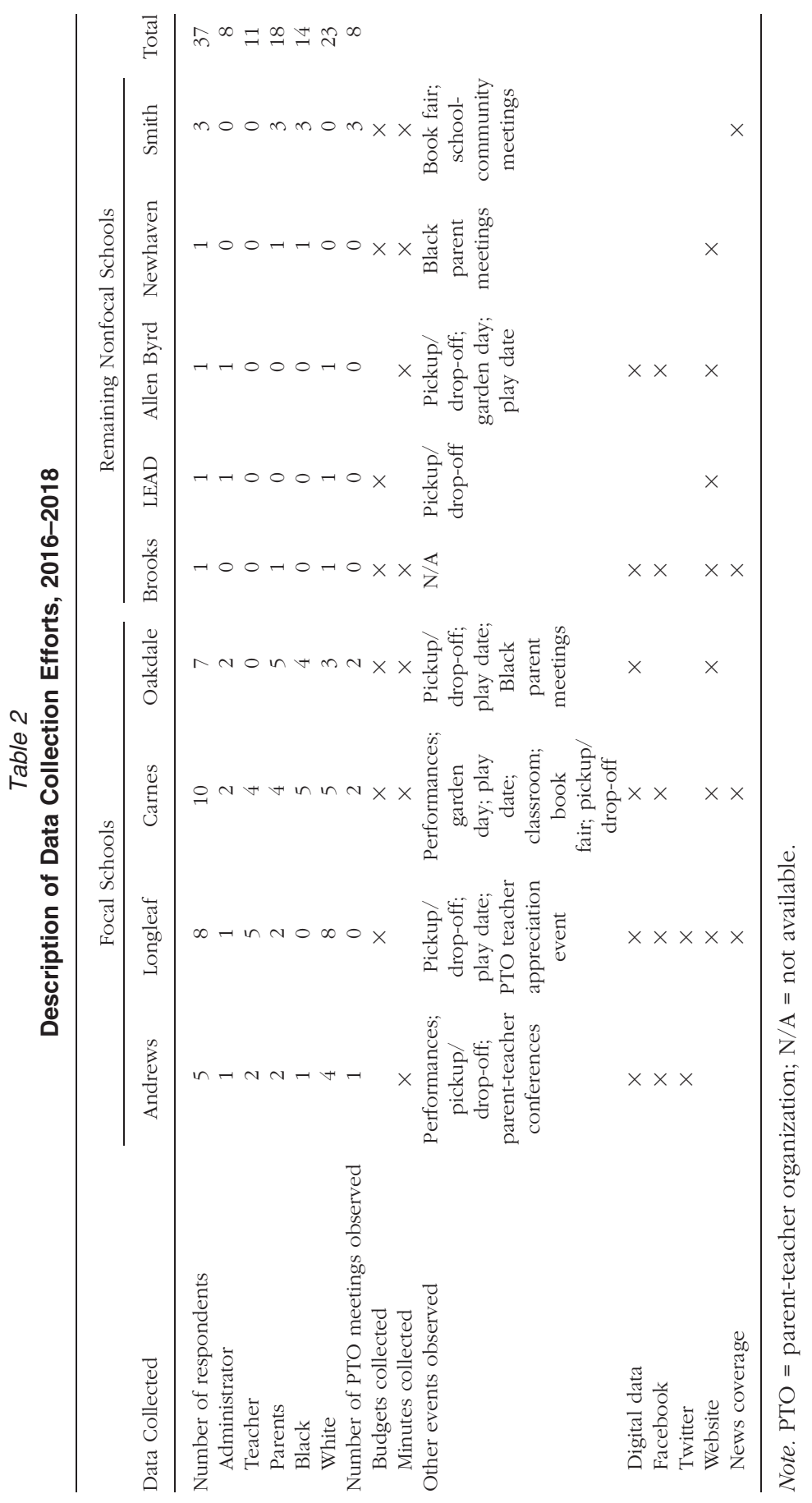


Murray et al.

\section{Ethnographic Observations}

In each school, we observed intersections of family and school life such as pickup and drop-off, parent-teacher conferences, and student assemblies. We observed eight PTO meetings where we took detailed notes on the demographics of meeting participants and meeting leaders, the topics they discussed, and participant engagement. We documented our observations of PTO meetings immediately after in detailed fieldnotes, and subsequently followed up with participants to contextualize their comments during meetings and rallies. These events also provided opportunities to hold dozens of informal conversations with parents, teachers, and administrators during the course of our ethnographic observations.

Participant observation of off-site parent meetings (e.g., in cafés and private homes) also proved to be fruitful. The lead fieldwork team member followed coalitions of parents, representing multiple schools in the study, as they mobilized to improve equity in the urban school district. We observed and participated in 10 meetings where parents facilitated introductions across networks, expressed grievances and concerns with school processes, strategized how to alleviate issues, or celebrated successes.

\section{Document Review}

For triangulation purposes, we collected documents such as school memos, school improvement plans, presentations to parents, event flyers, and parent surveys. We also collected PTO meeting agendas, budgets, and minutes. These budget documents supported our efforts to confirm and disconfirm stakeholder reports of PTO priorities and expenditures.

\section{Social Media Analysis}

In addition to attending face-to-face meetings, parents engaged extensively with the PTO using social media. Therefore, we examined the ways in which PTOs engaged parents electronically via PTO listservs, websites, Facebook, and Twitter. We archived electronic communications from throughout our observation period documenting requests for donations and volunteerism, calls to advocacy, event announcements, informative posts, and discussions of controversial topics. We also took note of who and how many parents engaged with their digital platform by tabulating comments and similar interactions.

\section{Analytic Strategy}

We employed an iterative and collaborative analysis process using both inductive and deductive coding techniques. First, two fieldwork team members manually coded interview transcripts and observation notes based on our initial bridging and bonding categories from our theoretical framework. 
This analysis specifically examined the nature of parent relationships, when those relationships were used for educational gain, and the school practices, programs, and structures that facilitated the activation of parent social capital. Team members met regularly to discuss emergent patterns and themes and generate hypotheses.

Next, team members jointly engaged in the constant comparative method of analysis (Glaser, 1965). We uploaded observation notes, interview transcripts, meeting documents, and web-scraped social media records into N-VIVO qualitative analysis software and Microsoft Excel. Two team members, one immersed in data collection and one removed, jointly coded all data sources looking explicitly for both support and disconfirming evidence for suggested hypotheses. The analysts compared incidents in which parent organization or the activation of parent social capital facilitated equity building or opportunity hoarding by coding three types of social processes among parents: (1) exchanges and distribution of knowledge and resources, (2) access to and influence over decision-making bodies, and (3) moments of inclusion and exclusion (Lareau \& Horvat, 1999). Team members regularly engaged in data reduction, memo-ing, and discussion to make inferences across incidents and across schools (Miles \& Huberman, 1994).

\section{Cross-School Variation in Bonding and Bridging Social Capital}

Parents in the schools we observed interacted via a wide range of practices, from educator-organized parent workshops and parent-led PTO meetings to spontaneous social gatherings in the playground. Some practices, such as school curriculum nights, were intended to share information and resources to diverse parent groups, lending themselves to the construction of bridging social capital. Others, such as playdates involving small groups of children and their parents, facilitated the creation of bonding social capital by maintaining information within a parent network. Table 3 provides a summary of the social capital-building practices we frequently observed as well as the form of social capital with which each is associated.

Diverse schools vary in the extent to which they employ social capitalgenerating practices. All schools implemented practices that led to the creation of both bridging and bonding social capital among parents; however, the range of programming and their frequency varied across schools. Additionally, a simple count of the number of bridging or bonding practices is insufficient because the ways in which these practices are implemented have implications for who can activate bridging and bonding social capital. For example, there is wide variation in the way in which PTO meetings are conducted. In some schools, PTO meetings are held monthly, encouraging dialogue among participants, welcoming those in attendance to provide feedback and challenge aspects of budgeting and programming. Some schools offer child care, dinner, translators, late start times and other 
Murray et al.

Table 3

Selected School Practices Contributing to Formation of Bridging and Bonding Social Capital

\begin{tabular}{|c|c|c|}
\hline Practice & Bridging & Bonding \\
\hline \multicolumn{3}{|l|}{ Programming } \\
\hline Curriculum nights & $x$ & \\
\hline Student performances & $x$ & \\
\hline Needy family assistance & $\times$ & \\
\hline Staff-student basketball games & $x$ & \\
\hline Classroom volunteering & & $\times$ \\
\hline Teacher appreciation events & & $\times$ \\
\hline Multicultural night & $x$ & \\
\hline Antiracism trainings & $\times$ & $\times$ \\
\hline School gardens & $x$ & $x$ \\
\hline Themed parent meetings & $x$ & \\
\hline Parent leadership training & $\times$ & $\times$ \\
\hline Black history month & $\times$ & \\
\hline Parent/grandparent days and ceremonies & $x$ & \\
\hline Child care/food provision & $\times$ & \\
\hline \multicolumn{3}{|l|}{ Communication } \\
\hline School websites & $\times$ & \\
\hline Social media pages & $x$ & $\times$ \\
\hline Principal voice messages & $\times$ & \\
\hline Translators and translated materials & $x$ & \\
\hline Weekly folders & $x$ & \\
\hline Morning announcements & $\times$ & \\
\hline Parent surveys & $x$ & \\
\hline \multicolumn{3}{|l|}{ Governance } \\
\hline School improvement team & $\times$ & \\
\hline Parent affinity groups & & $\times$ \\
\hline Parent-principal advisory boards & $x$ & \\
\hline Parent advocacy groups & & $\times$ \\
\hline PTA general body meetings & $\times$ & \\
\hline PTA board meetings & $x$ & $\times$ \\
\hline Planning committees & $x$ & $\times$ \\
\hline District policy meetings & $x$ & \\
\hline \multicolumn{3}{|l|}{ Informal } \\
\hline School playdates & & $\times$ \\
\hline Pickup/drop-off & & $\times$ \\
\hline
\end{tabular}

Note: These practices vary in the extent to which they contribute to bridging and bonding social capital depending on how accessible they were to the broader school population. PTA $=$ parent-teacher association . 


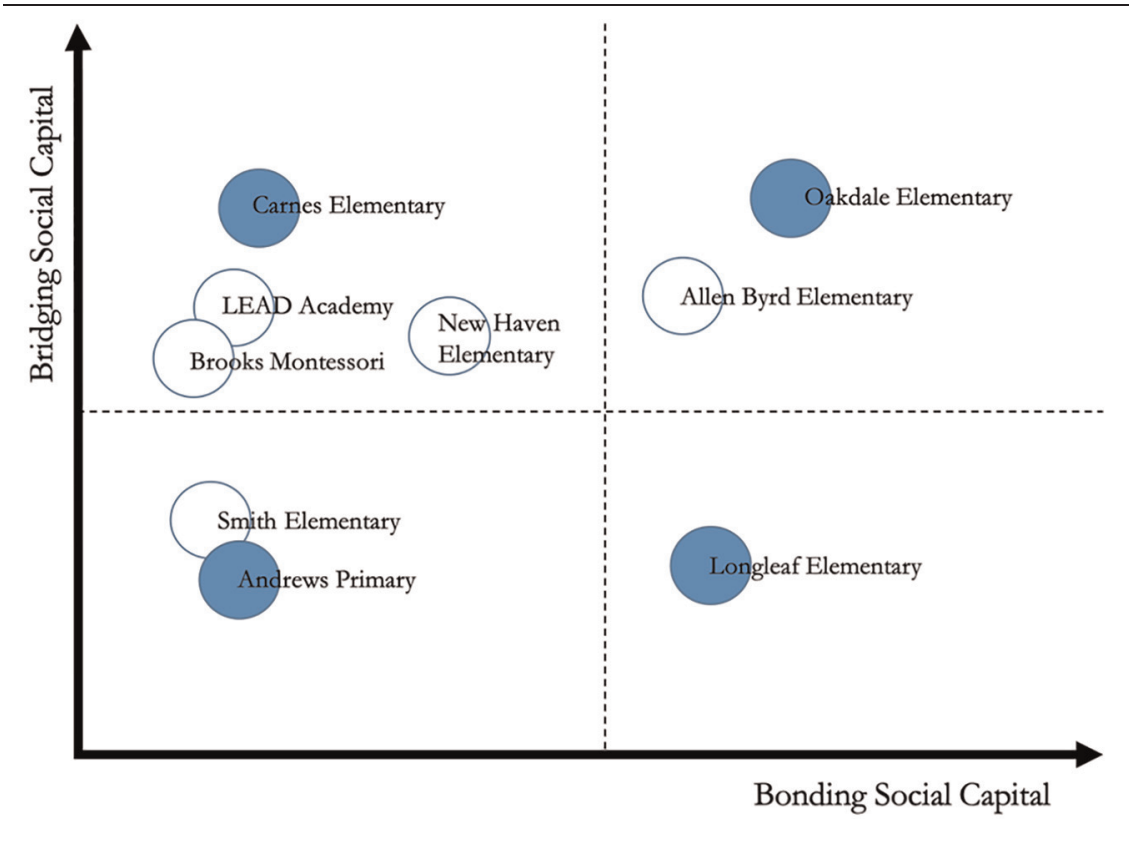

Figure 1. Bridging and bonding matrix with nine sampled schools.

accommodations for parents who work. Others, however, hold general body PTO meetings during the school day, once per semester limiting the ability of parents who work full time to attend. Still others send information only in one direction, leaving all decision-making authority within the small group of PTO board members.

Using counts of bridging and bonding practices and notes from the ways in which practices were carried out and the ability for parents to extract utility from their interactions, we identified a pattern in the structure of parent relationships in schools corresponding to the four quadrants on the bonding/bridging matrix in Figure 1: "low bridging-low bonding," "low bridging-high bonding," "high bridging-low bonding," and "high bridginghigh bonding." These ideal types serve as useful devices to investigate linkages between school practices and the forms of parent-activated social capital. We selected one school most emblematic of each ideal type to study more exhaustively, represented as blue circles on Figure 1.

The following sections present each of the four focal schools in the form of a school case study. We conclude with a cross-school analysis of the social processes that contribute to bridging and bonding social capital as well as their observed linkages with educational equity. 
Murray et al.

Every Man for Himself: Low-Bridging and Low-Bonding in Andrews Primary

Andrews Primary ${ }^{2}$ is a small, rural school located on the fringe of a wealthy resort community. Referred to as the "red-headed stepchild" by educators of the county's majority-White school system, NCES reports that two thirds of Andrews' 333 students are Black and Latinx, and nearly 80\% receive subsidized lunch. The level of student need is incredible: According to the principal, half of prekindergarten students come in with an individualized education plan. Geography alone partly explains its status as a low-bridging and low-bonding school. The principal explained that the school is located near the border of three counties, and many Andrews' families move in and out of the school catchment area as rents rise and fall. Many students live dozens of miles away, meaning long bus rides and drop-offs during their parents' morning and evening commutes. Andrews only offers prekindergarten through second grade, and parents often rush through the drop-off line as they hurry to deliver children to neighboring preschools, elementary, and upper-level schools.

Andrews has little bridging or bonding social capital. Although the school has a PTO structure in place, the PTO has almost no revenue and is largely inactive. There is tension between the new principal, a young White woman tasked to implement a turnaround plan, and a group of Black veteran teachers. Parents are also divided about the new principal. Socioeconomic and racial tensions are at least partially to blame. When asked informally, some parents complained that the administration's use of email and social media leave poor parents in the dark. One Black parent says that the principal banned her from the school and threatened to charge her with trespassing after she came to talk with her son at lunch. This mother says, "I don't think [the principal] connects with her parents, I don't see a lot of Black parents over there at all."

Even among parents, social connections appear to be relatively sparse. One White teacher notes that despite a shared history in the small town, long-running conflicts divide families creating a school ethos of every man for himself: "There can be some animosity between parents. That's happened a few times this year where I don't want my child in a classroom with him because we don't like his family."

Acknowledging that she has less contact with parents than she would like, the principal notes that many families at Andrews have little time and few resources to devote to school:

You have the moms that are always working 2 and 3 jobs. And you'll never see them, but if you call them and say I need something, it's gonna get here. You might not see them, though. Or if you call because of a discipline issue or something like that. If they're not here to take care of business they will tell me a family member is going to be here. But you can tell they're doing everything in their power to make ends meet. 
Nonetheless, the principal and other Andrews' educators feel they go out of their way to increase the frequency of parent interactions with the school. Once a semester, they host literacy and/or math nights to familiarize parents with school goals and testing schedules. Andrews schedules these events to correspond with student performances and offers food and child care to encourage broad participation. Andrews' educators boasted of high turnout at school-led events during interviews. However, parents have few opportunities to initiate activities in the school. Consistent with our characterization of Andrews as a school with low levels of bonding and bridging social capital, parents and educators agree that parental involvement in the school is individualistic. Parents keep tabs on their own child's progress through parent-teacher conferences, individualized education plan meetings, and/or phone calls with the teachers, but parents have few opportunities to speak to one another or work together in the school context.

Andrews' PTO consists of a handful of White mothers. PTO leadership appears to build bonding social capital with each other and the administration over the shared goal of fund-raising for teacher appreciation events with the hopes of funding additional teacher assistants. The PTO also sponsors irregular socials for teachers such as appreciation luncheons. However, the PTO is highly dependent on the administration and is often inactive for years at a time. During our observation period, the PTO was primarily led by the school administration and a PTO president, a White woman who organizes most events while looping in friends to help with discrete tasks.

The PTO draws on out-of-school networks to secure in-kind donations and raise money using the underdog status of the school for emotional appeal, yet they have not bridged with any other groups of parents to make decisions about programming or how supplemental resources are allocated. Although the PTO pairs meetings with schoolwide events to garner more participation, any mention of gaining involvement from disconnected parents is targeted toward getting them on a contact and Facebook list where they devote the majority of their posts to asking for donations or time. In a packed gym with hundreds of predominantly Black and Latinx parents and family members excitedly cheering on their children during a winter performance, the energy immediately left the room once the White PTO president took the microphone to read announcements about eating at a local restaurant for Spirit Night and inviting donations for a canned food drive. Parents began leaving the gym disengaged. The subsequent lack of bridging social capital provides fertile ground for opportunity hoarding at Andrews Primary, where a small group of middle-class White women maintain direction over the school's small pool of resources. 
Murray et al.

\section{Parental Glue: Low-Bridging and High-Bonding in Longleaf Elementary}

Just a few miles from Andrews, nestled in the heart of a small yet bustling village, sits Longleaf Elementary, which serves primarily affluent, White students. The town boasts of its nostalgic southern charm, and the school blends in seamlessly with the traditional aesthetic of the community. A quick search on Realtor.com reveals surrounding home values starting in the half million-dollar range. Families walk to church, to local restaurants and shops, and many parents walk their children to and from school daily. Even driving parents park and walk their children directly to their buildings and classrooms creating walk-up traffic that according to the school's principal, a White woman, is "unlike anything you've ever seen."

Parents and educators agree that relationships at Longleaf are tight-knit, particularly among a core group of high-resourced parents and teachers. The Longleaf PTO vice president, a White woman, lists the many occasions in which mothers and children interact, including informal after-school playground sessions, school clubs, and the country club pool. "Inevitably, your child comes up or school or a teacher . . . The discussion just kind of tends to go towards that." Even on social media, it is easy to get the sense that parents know each other. Longleaf has the most Facebook engagement of our four focal schools with six times the number of page followers, twice the number of posts than the others, as well as the broadest constituency of active engagers. Moreover, the posts most likely to garner interactions are not those to share information or broadcast events but rather those that share images of children around campus, sometimes in the butterfly garden or other times engaging in a schoolwide scavenger hunt.

Despite these efforts to build schoolwide connections via social media, teachers stated that it is usually the same "helicopter" parents who volunteer in classrooms, show up for school events, and serve on committees. As one teacher reports, "I have my few parents that I know I can email and call when I need them. It's the same thing school-wide, you know the families that are able to do that." The bonding social capital among this tight-knit group of parents gives them access to insider information about what is happening in their children's classrooms. This bonding social capital also creates opportunities for this group of advantaged parents to influence school-level processes and negotiate with teachers for their child's best interest.

I think a parent who is here all the time, who knows what's going on, who is volunteering, whose face is seen, um, can advocate for the child easier because they know they have a relationship with the teachers and the administration, so it becomes a natural conversation. Where if we never see you and you come in and, all of a sudden, try to advocate for your child, it's not what we wouldn't listen, but it's different. It's not a relationship. (Longleaf Elementary teacher, White woman) 
Bonded relationships are also central to PTO operations. While over half of Longleaf's 532 student families regularly pay \$5 PTO dues, only about 20 parents regularly attend meetings. Parents recruited to the board are looped in through friendship networks, leaving little opportunity for outside parent involvement. Most PTO planning for the year happens during the summer between the three to five board members and the principal. The PTO updates the broader PTO body and approves budgets in the first of three annual open meetings, but many decisions are made behind closed doors between the PTO president and the principal exclusively. Called a "control freak," by the PTO leadership, the principal ultimately weighs in on all PTO decisions and financial allocations. When asked about the decision to invest nearly $\$ 13,000$ in new playground shades, the PTO vice president revealed the decision was made among the board, this time without principal discretion, and approved by "a handful of people who come to the meetings."

Bonded social relationships among Longleaf's affluent White families and teachers excludes an underrepresented population of Black families from school social life. While the affluent White students employ a "walking school bus" to allow families to partner in their daily commute to schools, most Black students at Longleaf are poor and ride the bus from a single, distant neighborhood recently annexed by the town. Teachers report sporadically attempting to bridge the divide between the minority families and the school's larger White, affluent population. However, these efforts have not successfully created substantial bridging social capital at Longleaf. Black and Latinx parents are not represented on school committees, do not attend the majority of after-school events and programs, and were rarely observed in the school throughout the day. Aside from holding parent meetings in the evenings, many school stakeholders have resolved that the lack of representation is beyond their control.

Although parents who are active in the PTO point to new water fountains and playground shades as evidence of efforts that benefit all students in the school, the PTO rarely considers issues of equity. Unlike most PTOs in our analysis, Longleaf's PTO did not provide any emergency funds for needy families. They made very few attempts at gaining participation from disconnected families. Many PTO events advertised on Facebook are silent auctions and raffles devoted to families with means to contribute. Indeed, the PTO vice president, a White woman, seemed surprised when we asked about efforts to help poor students:

If a teacher comes to us specifically with, you know, "this kid needs this," then we would definitely provide that. But honestly, that hasn't, in the two years that I've been on the board, I don't remember getting any requests for that. ... Um, so, and we, since I've been on the board, we have not done something just for the low socioeconomic kids. And again, I'm not sure if we could even just target, target that group. 
Murray et al.

In the absence of bridging social capital, the needs of relatively disadvantaged students are almost invisible to the tight-knit group of affluent families that manage Longleaf's PTO. As a result, this organization works to direct opportunities and resources toward the school's affluent White students and away from its poorer Black and Latinx students.

\section{Bridges to Nowhere: High-Bridging and Low-Bonding in Carnes Elementary}

Carnes Elementary is situated in a predominantly White and affluent suburban school district. While the district is known for high-quality schooling and liberal politics, its large and persistent racial achievement gaps are oft-cited in local news outlets. Carnes is in a historically Black neighborhood and the school's pictures and murals pay homage to the town's most revered Black figures and institutions. The school opened in 2013 to relieve overcrowding in the district's most highly sought-after elementary schools, and many affluent parents resisted rezoning to the school. Carnes now serves an ethnically diverse group of about 500 students, approximately $40 \%$ of whom qualify for free or reduced-price lunch. Respondents note lingering distrust between the White families zoned into the school, the poorer Black and Latinx families who live in the school's immediate neighborhood, and the school's predominately Black leadership.

With a student body composition so large and diverse, the administration prioritizes bridging to garner families' trust and build a community in which families feel they belong. Bonded relationships are less prevalent as most students are geographically dispersed, and the new convergence of cultures and interests has made generating solidarity particularly challenging. Rezoned families share an identity over their plight of being, as a White PTO parent describes, "torn away at the roots" from their old schools. For many of these families, the PTO is an important mechanism for insuring that rezoned students receive the same advantages they did in their home schools. Reflecting on why so many White, affluent moms took on parent leadership positions, the PTO president, a White stay-at-home mom, told us,

The first year, you know, everybody was new. We were coming from all parts of the district, really. And so there was less that feeling of community and it was more a feeling of loss. . . There was this feeling of loss and not suspicion, but just sort of skepticism as to how this was going to go .... So it was different. It was a change. So, I think the first year was really a lot of getting to know one another and understanding that we do still have shared goals. And you know with the administration there was a lot of emphasis on setting expectations and rules and discipline and things like that, which didn't sit well with, I think, a lot of people.

While this group of affluent White parents is influential, the administration and staff make a concerted effort to build social capital by including 
other parents in the school community. Teachers employ the school website, educational apps, email, and "Friday folders" in children's backpacks to share regular newsletters, daily schedules, field trip information, classroom calendars, supply lists, and updates on their child's academic and social development with parents. Teachers also coordinate many family-oriented programs throughout the year alternating themes such as literacy, math, technology, health and wellness, and gifted and special education that appeal to parent interest groups.

The principal works to ensure that diverse perspectives are represented on the PTO and the school improvement team. For example, in its first year, the mostly White parent-led PTO struggled with transparency and attendance. At the principal's recommendation, the PTO moved the meeting time to evenings and dedicated a portion of meeting time to student performances coordinated by teachers. These moves helped boost attendance. The principal also partners with PTO parents to administer an annual parent survey to solicit feedback and works to incorporate suggestions into the school's and the PTO's practices. The principal, a Black woman, recounts,

what one of the parents shared was that you arrive at the meeting and you're given a series of data points or information or you're voting on the budget. It doesn't feel like that there's an opportunity to say, no. I don't think they wanted to say no, but they were saying if I had this information in advance it would feel like I'm doing more than just signing off on someone's thought. So, what the PTO, what we've been working on this year is sending out a budget in advance so that people have an opportunity to look over. So, if there are questions, then people feel like there is a real solicitation of their feedback.

Interview data suggest that many parents appreciate these efforts at inclusion. One Black mother who is highly involved in the PTO told us that she feels the school is "always willing to hear my voice." She contrasts this feeling with the school her child previously attended, where "if you weren't a certain socioeconomic status you wouldn't be heard."

Despite these efforts at bridging, relationships between parents, teachers, and administrators at Carnes have been contentious. Several respondents suggest that many affluent White parents pulled their children from Carnes in the school's first years of operation. More recently, controversy erupted when an outside donor funded a part-time librarian to staff the school library throughout the summer so that students without transportation to the city library would have access to summer books and programming. The school counselor resisted advertising the program to the entire school community because she worried affluent parents would hoard this educational resource by crowding out poorer neighborhood students. Recounting the resulting pushback, one Carnes teacher, a Black woman, told us, 
Murray et al.

Well, people who are not in the walk zone felt some kind of way about why this was being offered to a select few. And then when we were able to ask them how many times a week do you go to the library with your child? And it was like, oh, 3 or 4 times a week. These families don't. So, I mean like why would you need to be here? And it was a mess. . . . What they failed to understand is that we're trying to provide the same opportunities for these kids that you're providing for your kids. They just don't have transportation to get to the library. So why are you screaming?

This micropolitical drama reveals how a lack of bonding social capital creates an atmosphere of distrust at Carnes, leading to deep cleavages among parents and between parents and school staff that center on the allocation of school resources. Bridging with outside organizations and disconnected families facilitated the flow of resources in this case, but the lack of bonding social capital between actors threatened its sustainability.

The school uses its digital accounts to promote bridging events such as student-staff basketball games, Black history dedications and programs, and equity and advocacy events. However, without bonding social capital among diverse parent groups, many parents appear mistrustful and unwilling to actively engage with school organizations leaving an overworked and homogeneous group of stakeholders at the helm of influential school committees. In one PTO meeting with about 30 in attendance, the researcher spoke briefly to the sole Black parent in attendance who expressed sentiments that he was not there to get involved with PTO programming but rather to monitor PTO decision making to make sure that Black students at the school were being treated fairly. Just a handful of White parents were vocal participants in PTO meetings and they struggled to get parents to volunteer and follow through with their requests, leaving a heavy burden on the backs of a few. Among those heavily involved, they express resentment over the amount of time they spend, sometimes expressing that it feels like a part-time job. They try to build bridges but it goes nowhere:

Everybody wants more communication, more communication. So, we do, and this makes me laugh, so much communication. We have like flyers and newsletters and email and all this stuff. And then the same people that asked for the communication like, well didn't you get the flier? Oh, I don't check his Wednesday folder. Did you read the newsletter, the beautiful PTA newsletter? Oh no, I unsubscribed from that. I don't have time for all that. (Carnes Elementary past PTO president, White woman)

\section{"We're in This Together": High-Bridging and High-Bonding in Oakdale Elementary}

Oakdale Elementary sits on the outskirts of a growing urban school district drawing children from a variety of neighborhoods. The school's 
expansive catchment area, coupled with the loose choice policies in the district, contributes to the school's large enrollment of just under 650 students. As a Title I school serving large populations of Black (55\%) and Latinx students (22\%), the level of need is high and test scores are low. The school is recognized for its success in achieving student growth and attracts Black and White affluent families by offering a welcoming, diverse environment. One Black mother, reflecting on how the principal successfully marketed the school to her despite concerns over the poor performance grade, recalled his reassuring words during a school tour:

He told me he had a student last year that was in the fourth grade that came in on a kindergarten and first grade reading level. By the end of the year, the child was on a third-grade reading level. "So," he said, "I will take that level of progress any day of the week, you know. But, that's not gonna show up on any report."

This parent, though not zoned to Oakdale, makes the additional effort to bring her son because of the school's efforts at inclusion. Even when compared with higher performing options she described as "sterile," she chose Oakdale.

The school adopts specific practices to build bonding social capital among stakeholders. Oakdale starts the official school day early to facilitate a 30-minute block for socialization, when all staff-teachers, custodians, admin, and office-greet families as they walk their children to class. By creating a venue for parents and teachers to regularly interact informally, the school supports the development of organic relationships among parents and between parents and staff, transitioning from simple introductions to coffee and after-school playdates. Oakdale's rich social capital create an ethos grounded in what the principal, a White man, describes as a "culture of we're in this together." The past PTO president, a working-class White man, attributes the familial school atmosphere to the formation of some of his closest friendships, specifically one with the incoming PTO president, a Black woman: "[We] didn't know each other before her daughter started kindergarten. But, through the school and just being together, you know, and doing stuff with the school all the time, you know, it's like I met another sister."

Oakdale administrators attempt to build bridging social capital by providing "something for everyone" in terms of programming and communication. They hold faculty-student basketball games, student performances, and morning meetings with families that alternate themes and target audiences. They employ multiple media to get information to parents ranging from Friday folders to websites and educational apps. The incoming PTO president lauded the principal for his support and partnership with parents saying that if the PTO has an announcement, the principal will let her record a message on the voicemail boxes of each family and post in the universal school app. These forms of direct communication eliminate the need for social media, which helps explain why the Oakdale PTO has no social media presence. 


\section{Murray et al.}

The administration works to understand parent needs and to design initiatives and direct resources in ways that will bridge across social divides. On learning that a mother was relying on the city bus for her and her child to attend school events, the principal recalls buying them a bus pass to alleviate travel expenses. Recognizing that there are still parents who have difficulty accessing the school, they attempt to reach disconnected families by offering a food pantry, backpack buddies, and a clothes closet. Another outreach strategy is Oakdale's annual block party in one low-income family apartment complex located about a mile from the school where the entire staff brings free food, free books, and music, and holds impromptu parent-teacher conferences. Reflecting on the block party, Oakdale's principal says, "Look, if you can't come to us that's okay. We'll come to you. We want to build that relationship so that then we can help you and you can help us. We can work this thing out together." This event attracts families from the broader Oakdale community, as well as increasing school contact among those living in the area.

Oakdale's PTO extends the administration's vision of an inclusive environment by working in partnership with the principal, both entities collaborating and taking advice from each other. Many PTO leaders work fulltime jobs, but the assistant principal, a White woman, says their commitment to public education and students sets them apart from less involved parents:

They're committed to this school, to this community . . because they're not all stay at home moms, most of them aren't, who have free time. They adjust their work schedules to be here, to do events, and it's, I think, caring is the main driving force.

Though only a small percentage of the large student body has officially joined the PTO, both the PTO membership and its leadership is demographically representative of the school population. The PTO contains a committee of Black parents that complements the organization's fund-raising focus with advocacy for racial equity. This Black parent committee holds separate meetings to bridge to Black parents who may not be drawn to the more formal PTO meetings but have an interest in closing racial achievement and opportunity gaps within the school. This committee gives Black parents a platform to bond with each other, share information, and direct general PTO resources toward Black students, or as the new PTO president, a Black woman, says, "making sure that each child is met where they are and has the resources that they need to be able to have a healthy education."

\section{The Process of Building Social Capital in Diverse Schools}

\section{Building Bonds}

Bonding social capital appears to accumulate primarily in relatively homogeneous settings. Longleaf Elementary, our low-bridging and highbonding case, demonstrates the relative ease by which tight-knit school 
communities build bonding social capital. Like-minded White, affluent families compose the majority of the school population and are in regular communication with each other around the school building facilitating the exchange of information, favors, and the co-monitoring of one another's children. Many teachers and even the principal are also parents of children at the school, allowing shared perspectives and overlapping identities to make school stakeholders feel their kids' best interests are represented. School programming is primarily taken up by the "core group," described by Longleaf educators as affluent families regularly visible in classrooms and around the school. This core group of parents interact regularly within and around the school building through after-school playdates, during afterschool sports and during pickup and drop-off.

\section{Bridging Takes Resources}

In contrast, because bridging social capital occurs when people make and mobilize connections across social distances, it can only occur in settings in which at least some form of social heterogeneity exists. However, even in schools with a high degree of racial/ethnic or socioeconomic diversity, bridged parent network structures do not form naturally. In diverse but low-resourced schools, lack of stakeholder time, money, and capacity on both the part of the educators and parents limit the ability to build relationships across the school.

Andrews and Smith, our low-bridging and low-bonding schools, serve high proportions of students receiving free or reduced-price lunch and serve almost even proportions of Black and Latinx students. In these schools, teachers are mainly concerned with updating parents on their own child's progress and providing guidance on how parents can help their child academically outside of school. School events designed to promote parent involvement are focused on raising test scores and leave few opportunities for meaningful interactions between families. Administrators and teachers report that they have little time and attention to devote to building relationships with parents, and PTOs go entire years without any activity. In active years, parent organizations are run by one to two parents while they struggle to gain enough parent support to delegate tasks and garner donations. The lack of resources and relationships across the school limits the ability for any individual to advance initiatives that might produce collective or individual benefits. For example, PTO leaders at Smith express frustration that the principal misses scheduled meetings, stifles progress through seemingly unnecessary bureaucracy, and stonewalls at meetings. They struggle to get the school on board with their plans.

\section{Bridging Takes Intentional Practices}

All the low-bridging schools represented in the bottom half of Figure 1 attempted to build relationships across disparate groups. However, these 
Murray et al.

efforts typically failed to make bridging practices routine. For example, Longleaf teachers worked collectively to plan an off-site curriculum night in the neighborhood that houses most of their poor Black students. Andrews' principal made a personal appeal to each individual parent to convince them to take part in a wildly successful book drive competition. Of the bridged relationships formed, the principal describes,

I had parents coming in that I've never seen before. Parents that I could not get to come in for a parent conference. Parents that were hesitant to ever even talk to me that were coming in and [saying], "we're gonna do this and we're gonna do it right!"

Such one-off efforts failed, however, to cultivate lasting relationships across their communities.

In contrast to Andrews and Longleaf, the schools we observed with higher degrees of bridging social capital intentionally accommodated the diverse needs and interests of families within the school community. At these schools, leaders ensured that school communications were available in multiple languages and provided information in multiple mediums to appeal to a range of parent accessibilities. Furthermore, these stakeholders intentionally planned events that reached across social boundaries. These events-including multicultural nights, where parents showcased traditional dishes; elaborate Black history month programming; and school gardens, which invited neighborhood families to spend their Saturday mornings harvesting fresh vegetables — created opportunities for communication and collaboration across social boundaries.

School leaders at high-bridging schools also intervened to increase racial/ethnic representation on school boards and committees. At these schools, administrators, teachers, and highly involved parents intentionally recruited parents from different backgrounds with the hopes that their unique perspectives would balance the predominantly White and affluent PTO boards and school improvement teams. In many cases, this resulted in a more racially diverse group of middle-class parents actively donating time and money to events and programs that drew interest and participation from all families in the building.

\section{Bonding, Bridging, and Educational Equity}

The extent of bridging and bonding social capital in a school has implications for educational equity. At Andrews and Smith, where we observed little bonding or bridging, parents found it difficult to work effectively to advance their children's educational careers. At Longleaf, by contrast, where we observed a high degree of bonding social capital but a low degree of bridging, opportunity hoarding prevailed among the White and affluent parents who were central to decision-making and resource allocation 
processes. This small subset of parents were unwilling or unable to redistribute resources and opportunities to families with the greatest need.

Although school committees and programs were visibly diverse at highbridging schools, bridging social capital alone is not enough to eliminate opportunity hoarding in diverse schools. Rather, the extent to which decisions about resource allocation were truly pluralistic aligned with the degree of bonding social capital. At high-bridging/low-bonding schools, like Carnes Elementary, we observed diverse involvement in parental organizations. However, in many of these schools, minority parents complained that White parents derailed efforts to advocate for children of color. One highly involved Black mother at New Haven Elementary (which we also characterized as high-bridging/low-bonding) recalls the (mostly White) PTO board changing the rules about how excess PTO funds are allocated after her successful proposal of directing those monies to "culturally inclusive programming" in consecutive years:

They changed the note to say that if there's additional money in special projects to do initiatives, it has to be a general membership vote as opposed to just a Board vote. Which means there's more hoops to jump through to get plans pushed.

As White, affluent parents are the more bonded group in our high-bridging/ low-bonding schools, they coalesce around their own goals and structure organizational rules and discretionary acts to support those goals. Although bridging social capital brings diverse perspectives about school programming and resource allocation to the table, minority parents are often marginalized and their ability to make substantive contributions is limited. New Haven, for example, devoted 50\% more of their 2017-2018 budget to improving the Montessori experience for students (Montessori conference, classroom materials/supplies, etc.) than they did to community-building efforts (Black Parents Committee, Latino Families Initiative, and Equity Team, etc.).

In contrast, schools that have high levels of both bridging and bonding social capital distribute educational resources most equitably. Oakdale and other high-bridging/high-bonding schools created multiple opportunities for parent leadership in integrated parent affinity and advocacy groups that negotiated for resources through a formal organizational hierarchy. Furthermore, these highly bridged and bonded communities provided mechanisms such as elections and parent surveys to decide which parents would serve as representatives and to influence school processes. These schools devote more in their budgets to cultural enrichment, parent leadership trainings, and field trips and camps for kids in need than they do to grounds improvements and programs that might only benefit a subset of the school population. Furthermore, parents at these schools played an important role in designing and executing schoolwide events. Parents 
Murray et al.

from diverse backgrounds had autonomy to direct resources to the schoolwide programming they felt most important for their communities. At Allen Byrd, for example, Black and Latinx parent affinity groups plan antiracism workshops for parents and staff, including Socratic seminars focused on equity. In communities with high-bonding and high-bridging social capital, parents had a safe space to share their needs and concerns among a group of like-minded parents as well as a platform to collectively advocate for and direct resources toward those needs.

\section{Conclusion}

Schools serve as a key context for understanding how social capital contributes to or reduces social inequality. Scholars have long maintained that strong ties between parents, teachers, and students can reduce inequality in schools (Coleman, 1988; Dika \& Singh, 2002; Kim \& Schneider, 2005; Li \& Fischer, 2017; Turley et al., 2017). This argument is an important inspiration for school choice movements in educational policy (Chubb \& Moe, 1990; Howell \& Peterson, 2002). However, while tight-knit relationships may reduce inequality in some situations; when a few bonded parents in heterogeneous schools use their relationships for individual gain, bonding social capital can also exacerbate inequality (Calarco, 2018; Cucchiara \& Horvat, 2009; Lareau \& Calarco, 2012; Lewis \& Diamond 2015).

Our observations of parental interactions in racially and socioeconomically diverse public elementary schools indicate that relatively advantaged parents form bonded relationships without substantial intervention from the school. However, educators and school practices have an important role to play in building social bonds among relatively disadvantaged parents and, especially, empowering disadvantaged parents to activate their social bonds in the school setting. Furthermore, schools must act intentionally to overcome social distances among diverse groups of parents in order to build and employ bridging social capital in school. Our case studies suggest that both the failure to ensure that all parents have access to bonding social capital and the failure to build social bridges among diverse parent constituencies comes at a high social cost. In the schools we observe, bonding without bridging facilitates opportunity hoarding among parents who maintain control and influence over school auxiliary functions. Bridging without bonding, meanwhile, is not sufficient to generate equitable resource allocation and shared decision making. Our case studies demonstrate the need to couple effective bridging with the development of social bonds among actors in order to create inclusive and responsive communities. Our findings thus modify dominant perspectives on social capital in schools by suggesting that closure and tight-knit relationships are important to equity but only when bridging social capital is present as well. 
Before discussing our findings' implications, we note several important limitations. Since our data are limited to a snapshot of nine schools at a single point in time, we cannot determine whether our observed trends persist over time. We do not know, for example, if the social divisions between advantaged PTO parents and the larger population at Carnes will diminish once the public memory of rezoning fades. We are also unable to predict whether the democratic PTO processes at Oakdale will survive an incoming class of zealous kindergarten parents. Furthermore, while our analyses suggest important hypotheses about the mechanisms that produce bonding and bridging social capital, we cannot know how well our findings generalize to other schools or to other social settings such as churches, neighborhoods, and noneducational civic organizations. While the North Carolina elementary schools we study are both racially and socioeconomically heterogeneous, we do not claim that they are representative. In particular, our analyses provide limited insight into social capital construction in communities with high rates of immigration and linguistic diversity.

Despite these limitations, the analyses presented here have important implications. In diverse situations, neither bridging nor bonding social capital alone is enough to generate equity. Both strong and weak relationships are necessary for equity building. But building both types of capital takes intentionality. Within the schools we evaluated, having more incisive, inclusive practices relates to the presence of both cross-school bonding and bridging parental relationship structures. While our findings suggest that poverty and social distance both make it more difficult to build social capital, we also find evidence to suggest that educators and parents have the power to construct more engaged and inclusive school communities. Since our research design is observational, we cannot make strong claims about the effects of school practices on parental social capital formation and activation. But based on our data, we hypothesize that when schools structure their school day to create opportunities for diverse parents to regularly interact, plan events that highlight student culture and achievements, create parent groups that give voice to diverse constituencies, and actively solicit input from traditionally marginalized communities, they counteract tendencies toward opportunity hoarding and help parents build the forms of social capital that have wide benefits.

Practitioners and policymakers should turn to scholarship that more formally models parent social networks in schools and tests the effectiveness of school practices designed to build and deploy both bridging and bonding forms of parental social capital (Ishimaru et al, 2016; Shoji et al., 2014). Our findings strongly suggest that when educators and parents actively work to empower diverse parents and create regular opportunities for parents to interact and build solidarity, they can create more equitable schools. 
Murray et al.

\section{ORCID iD}

Brittany Murray (iD) https://orcid.org/0000-0002-6447-6249

\section{Notes}

This material is based in part on work supported by the National Science Foundation under Grant Numbers SES-1626891. Any opinions, findings, and conclusions or recommendations expressed in this material are those of the author(s) and do not necessarily reflect the views of the National Science Foundation.

${ }^{1}$ PTO revenue identified using nonprofit tax filings with Internal Revenue Service accessed via Urban Institute's National Center for Charitable Statistics (NCCS). Murray et al. (2019) identify the universe of parent-teacher associations, parent-teacher organizations, parent-student-teacher associations, school booster clubs, and other nonprofits directly available in NCCS Core files and BMF (Business Master Files) affiliated with North Carolina public elementary schools between 1999 and 2015 and documents year to year variation in revenue.

${ }^{2}$ All names are changed to pseudonyms.

\section{References}

Abrams, L. S., \& Gibbs, J. T. (2002). Disrupting the logic of home-school relations: Parent involvement strategies and practices of inclusion and exclusion. Urban Education, 37(3), 384-407. https://doi.org/10.1177/00485902037003005

Astone, N. M., \& McLanahan, S. S. (1991). Family structure, parental practices and high school completion. American Sociological Review, 56(3), 309-320. https://doi.org/10.2307/2096106

Ball, S. J., \& Vincent, C. (1998). I heard it on the grapevine: "Hot" knowledge and school choice. British Journal of Sociology of Education, 19(3), 377-400. https://doi.org/10.1080/0142569980190307

Biernacki, P., \& Waldorf, D. (1981). Snowball sampling: Problems and techniques of chain referral sampling. Sociological Methods \& Research, 10(2), 141-163. https://doi.org/10.1177/004912418101000205

Borgatti, S. P., \& Halgin, D. S. (2011). On network theory. Organization Science, 22(5), 1168-1181. https://doi.org/10.1287/orsc.1100.0641

Bourdieu, P. (1986). The forms of capital. In J. G. Richardson (Ed.), Handbook of theory and research for the sociology of education (pp. 241-258). Greenwood Press.

Bridwell-Mitchell, E. N. (2017). Them that's got: How tie formation in partnership networks gives high schools differential access to social capital. American Educational Research Journal, 54(6), 1221-1255. https://doi.org/10.3102/0002 831217717815

Bridwell-Mitchell, E. N., \& Cooc, N. (2016). The ties that bind: How social capital is forged and forfeited in teacher communities. Educational Researcher, 45(1), 717. https://doi.org/10.3102/0013189X16632191

Bryk, A. S., \& Schneider, B. (2003). Trust in schools: A core resource for school reform. Educational leadership, 60(6), 40-45.

Bryk, A. S., Sebring, P. B., Allensworth, E., Luppescu, S., \& Easton, J. Q. (2010). Organizing schools for improvement: Lessons from Chicago. University of Chicago Press.

Burt, R. S. (1999). The social capital of opinion leaders. Annals of the American Academy of Political and Social Science, 566(1), 37-54. https://doi.org/ 10.1177/000271629956600104 
Burt, R. S. (2000). The network structure of social capital. Research in Organizational Behavior, 22, 345-423. https://doi.org/10.1016/S0191-3085(00)22009-1

Calarco, J. M. (2018). Negotiating opportunities: How the middle class secures advantages in school. Oxford University Press.

Carbonaro, W. J. (1998). A little help from my friend's parents: Intergenerational closure and educational outcomes. Sociology of Education, 71(4), 295-313. https:// doi.org/10.2307/2673172

Centola, D. (2011). An experimental study of homophily in the adoption of health behavior. Science, 334(6060), 1269-1272. https://doi.org/10.1126/science.1207055

Chubb, J. E., \& Moe, T. M. (1990). America's public schools: Choice is a panacea. Brookings Review, 8(3), 4-12. https://doi.org/10.2307/20080159

Coburn, C. E., Mata, W. S., \& Choi, L. (2013). The embeddedness of teachers' social networks: Evidence from a study of mathematics reform. Sociology of Education, 86(4), 311-342. https://doi.org/10.1177/0038040713501147

Coleman, J. S. (1988). Social capital in the creation of human capital. American Journal of Sociology, 94, S95-S120. https://doi.org/10.1086/228943

Coleman, J. S. (1990a). Do students learn more in private schools than in public schools? James Madison Institute for Public Policy Studies.

Coleman, J. S. (1990b). Foundations of Social Theory. Belknap.

Comer, J. P. (1980). School power: Implications of an intervention project. Free Press.

Comer, J. P. (2015). Developing social capital in schools. Society, 52(3), 225-231. https://doi.org/10.1007/s12115-015-9891-5

Crawford, S., \& Levitt, P. (1999). Social change and civic engagement: The case of the PTA. In T. Skocpol \& M. P. Fiorina (Eds.), Civic engagement in American democracy (pp. 249-296). Brookings Institution Press.

Crosnoe, R., \& Cooper, C. E. (2010). Economically disadvantaged children's transitions into elementary school: Linking family processes, school contexts, and educational policy. American Educational Research Journal, 47(2), 258-291. https://doi.org/10.3102/0002831209351564

Cucchiara, M. B., \& Horvat, E. M. (2009). Perils and promises: Middle-class parental involvement in urban schools. American Educational Research Journal, 46(4), 974-1004. https://doi.org/10.3102/0002831209345791

Daly, A. J. (Ed.). (2010). Social network theory and educational change. Harvard Education Press.

Dika, S. L., \& Singh, K. (2002). Applications of social capital in educational literature: A critical synthesis. Review of Educational Research, 72(1), 31-60. https:// doi.org/10.3102/00346543072001031

Domina, T., Penner, A., \& Penner, E. (2017). Categorical inequality: Schools as sorting machines. Annual Review of Sociology, 43(1), 311-330. https://doi.org/10.1146/ annurev-soc-060116-053354

Fine, M. (1993). [Ap]parent involvement: Reflections on parents, power, and urban public schools. Teachers College Record, 94(4), 682-710.

Fong, K., \& Faude, S. (2018). Timing is everything: Late registration and stratified access to school choice. Sociology of Education, 91(3), 242-262. https:// doi.org/10.1177/0038040718785201

Frank, K., Lo, Y., Torphy, K., \& Kim, J. (2018). Social networks and educational opportunity. In B. Schneider (Ed.), Handbook of the sociology of education in the 21st century (pp. 297-316). https://doi.org/10.1007/978-3-319-76694-2_13

Glaser, B. G. (1965). The constant comparative method of qualitative analysis. Social Problems, 12(4), 436-445. https://doi.org/10.2307/798843

Granovetter, M. S. (1973). The strength of weak ties. American Journal of Sociology, 78(6), 1360-1380. https://doi.org/10.1086/225469 


\section{Murray et al.}

Greene, J. C., Caracelli, V. J., \& Graham, W. F. (1989). Toward a conceptual framework for mixed-method evaluation designs. Educational Evaluation and Policy Analysis, 11(3), 255-274. https://doi.org/10.3102/01623737011003255

Horvat, E. M., Weininger, E. B., \& Lareau, A. (2003). From social ties to social capital: Class differences in the relations between schools and parent networks. American Educational Research Journal, 4O(2), 319-351. https://doi.org/10.31 02/00028312040002319

Howell, W. G., \& Peterson, P. E. (2002). The education gap: Vouchers and urban schools. Brookings Institution Press. https://doi.org/10.7864/j.ctt128086

Ishimaru, A. M., Torres, K. E., Salvador, J. E., Lott, J., Williams, D. M. C., \& Tran, C. (2016). Reinforcing deficit, journeying toward equity: Cultural brokering in family engagement initiatives. American Educational Research Journal, 53(4), 850882.

Kalil, A., Ziol-Guest, K. M., Ryan, R. M., \& Markowitz, A. J. (2016). Changes in income-based gaps in parent activities with young children from 1988 to 2012. AERA Open, 2(3). https://doi.org/10.1177/2332858416653732

Kim, D. H., \& Schneider, B. (2005). Social capital in action: Alignment of parental support in adolescents' transition to postsecondary education. Social Forces, 84(2), 1181-1206.

Lareau, A. (2000). Home advantage: Social class and parental intervention in elementary education. Rowman \& Littlefield.

Lareau, A., \& Calarco, J. M. (2012). Class, cultural capital, and institutions: The case of families and schools. In S. T. Fiske \& H. R. Markus (Eds.), Facing social class: How societal rank influences interaction (pp. 61-86). Russell Sage Foundation.

Lareau, A., \& Goyette, K. (2014). Choosing homes, choosing schools. Russell Sage Foundation.

Lareau, A., \& Horvat, E. M. (1999). Moments of social inclusion and exclusion race, class, and cultural capital in family-school relationships. Sociology of Education, 72(1), 37-53. https://doi.org/10.2307/2673185

Lareau, A., \& Muñoz, V. L. (2012). "You're not going to call the shots": Structural conflicts between the principal and the PTO at a suburban public elementary school. Sociology of Education, 85(3), 201-218. https://doi.org/10.1177/ 0038040711435855

Lareau, A., Weininger, E., \& Cox, A. (2018). Parental challenges to organizational authority in an elite school district: The role of cultural, social, and symbolic capital. Teachers College Record, 120(1).

Larsen, L., Harlan, S. L., Bolin, B., Hackett, E. J., Hope, D., Kirby, A., Nelson, A., Rex, T. R., \& Wolf, S. (2004). Bonding and bridging: Understanding the relationship between social capital and civic action. Journal of Planning Education and Research, 24(1), 64-77. https://doi.org/10.1177/0739456X04267181

Lewis, A. E., \& Diamond, J. B. (2015). Despite the best intentions: How racial inequality thrives in good schools. Oxford University Press.

Lewis-McCoy, R. L. (2014). Inequality in the promised land: Race, resources, and suburban schooling. Stanford University Press.

Li, A., \& Fischer, M. J. (2017). Advantaged/disadvantaged school neighborhoods, parental networks, and parental involvement at elementary school. Sociology of Education, 90(4), 355-377. https://doi.org/10.1177/0038040717732332

Lin, N. T. (1999). Building a network theory of social capital. Connections, 22(1), 28-51.

McPherson, M., Smith-Lovin, L., \& Cook, J. M. (2001). Birds of a feather: Homophily in social networks. Annual Review of Sociology, 27(1), 415-444. https://doi.org/ 10.1146/annurev.soc.27.1.415 
Miles, M. B., \& Huberman, A. M. (1994). Qualitative data analysis: An expanded sourcebook. Sage.

Minefee, I., Rabelo, V., Stewart, O., \& Young, N. (2018). Repairing leaks in the pipeline: A social closure perspective on underrepresented racial/ethnic minority recruitment and retention in business schools. Academy of Management Learning E Education, 17(1), 79-95. https://doi.org/10.5465/amle.2015.0215

Murray, B., Domina, T., Renzulli, L., \& Boylan, R. (2019). Civil society goes to school: Parent-teacher associations and the equality of educational opportunity. RSF: The Russell Sage Foundation Journal of the Social Sciences, 5(3), 41-63. https://doi.org/10.7758/RSF.2019.5.3.03

Mutz, D. C. (2002). Cross-cutting social networks: Testing democratic theory in practice. American Political Science Review, 96(1), 111-126. https://doi.org/10.1017/ S0003055402004264

Noguera, P. (2001). Transforming urban schools through investments in the social capital of parents. In S. Saegert, J. P. Thompson, \& M. R. Warren (Eds.), Social capital and poor communities (pp. 189-207). Russell Sage Foundation.

Oakes, J. (2005). Keeping track. Yale University Press.

Paxton, P. (1999). Is social capital declining in the United States? A multiple indicator assessment. American Journal of Sociology, 105(1), 88-127. https://doi.org/ $10.1086 / 210268$

Polletta, F., \& Jasper, J. M. (2001). Collective identity and social movements. Annual Review of Sociology, 27(1), 283-305. https://doi.org/10.1146/annurev.soc.27.1.283

Portes, A. (1998). Social capital: Its origins and applications in modern sociology. Annual Review of Sociology, 24(1), 1-24. https://doi.org/10.1146/annurev .soc. 24.1.1

Posey-Maddox, L. (2014). When middle-class parents choose urban schools: Class, race, and the challenge of equity in public education. University of Chicago Press.

Putnam, R. D. (2001). Bowling alone: The collapse and revival of american community. Simon \& Schuster.

Reardon, S. F. (2011). The widening academic achievement gap between the rich and the poor: New evidence and possible explanations. In G. J. Duncan \& R. J. Murnane (Eds.), Whither opportunity? Rising inequality, schools, and children's life chances (pp. 91-116). Russell Sage Foundation.

Roscigno, V. J. (2007). The face of discrimination: How race and gender impact work and home lives. Rowman \& Littlefield.

Sattin-Bajaj, C., Jennings, J. L., Corcoran, S. P., Baker-Smith, E. C., \& Hailey, C. (2018). Surviving at the street level: How counselors' implementation of school choice policy shapes students' high school destinations. Sociology of Education, 91(1), 46-71. https://doi.org/10.1177/0038040717751443

Schensul, S. L., Schensul, J. J., \& LeCompte, M. D. (1999). Essential ethnographic methods: Observations, interviews, and questionnaires. AltaMira Press.

Shoji, M. N., Haskins, A. R., Rangel, D. E., \& Sorensen, K. N. (2014). The emergence of social capital in low-income Latino elementary schools. Early Childhood Research Quarterly, 29(4), 600-613. https://doi.org/10.1016/j.ecresq.2014 .07 .003

Skocpol, T., \& Fiorina, M. P. (Eds.). (2004). Civic engagement in American democracy. Brookings Institution Press.

Small, M. L. (2009a). "How many cases do I need?" On science and the logic of case selection in field-based research. Ethnography, 10(1), 5-38. https://doi.org/ $10.1177 / 1466138108099586$ 


\section{Murray et al.}

Small, M. L. (2009b). Unanticipated gains: Origins of network inequality in everyday life. Oxford University Press.

Stake, R. E. (2006). Multiple case study analysis. Guilford Press.

Stanton-Salazar, R. (1997). A social capital framework for understanding the socialization of racial minority children and youths. Harvard Educational Review, 67(1), 1-41. https://doi.org/10.17763/haer.67.1.140676g74018u73k

Teachman, J. D., Paasch, K., \& Carver, K. (1997). Social capital and the generation of human capital. Social Forces, 75(4), 1343-1359. https://doi.org/10.1093/sf/ 75.4.1343

Tedin, K. L., \& Weiher, G. R. (2011). General social capital, education-related social capital, and choosing charter schools. Policy Studies Journal, 39(4), 609-629. https://doi.org/10.1111/j.1541-0072.2011.00424.x

Tilly, C. (1998). Durable inequality. University of California Press.

Tomaskovic-Devey, D. (1993). Gender and racial inequality at work: The sources and consequences of job segregation. Cornell University Press.

Turley, R. N. L., Gamoran, A., McCarty, A. T., \& Fish, R. (2017). Reducing children's behavior problems through social capital: A causal assessment. Social Science Research, 61, 206-217. https://doi.org/10.1016/j.ssresearch.2016.06.015

Uzzi, B. (1997). Social structure and competition in interfirm networks: The paradox of embeddedness. Administrative Science Quarterly, 42(1), 35-67. https:// doi.org/10.2307/2393808

Useem, E. L. (1992). Middle schools and math groups: Parents' involvement in children's placement. Sociology of Education, 65(4), 263-279. https://doi.org/ $10.2307 / 2112770$

Wilson, W. J. (1987). The truly disadvantaged: The inner city, the underclass, and public policy (2nd ed.). University of Chicago Press.

Woyshner, C. (2003). Race, gender, and the early PTA: Civic engagement and public education, 1897-1924. Teachers College Record, 105(3), 520-544. https:// doi.org/10.1111/1467-9620.00249

Yin, R. K. (2014). Case study research. Sage.

Manuscript received September 14, 2018

Final revision received January 2, 2020

Accepted January 13, 2020 